\title{
Employment Experience of Immigrant Workers in Tourism
}

\author{
Alja Žigo \\ University of Primorska, Faculty of Tourism Studies - Turistica, Slovenia \\ alja.zigo@gmail.com \\ Janja Gabruč \\ University of Primorska, Faculty of Tourism Studies - Turistica, Slovenia \\ janja.gabruc@fts.upr.si \\ Emil Juvan \\ University of Primorska, Faculty of Tourism Studies - Turistica, Slovenia \\ emil.juvan@fts.upr.si
}

This research explores the experience of immigrants employed in tourism in Slovenia. Four main areas were studied: (1) formal regulation of working and living, (2) health and social care, (3) job satisfaction, and (4) integration into the Slovenian environment. The causes for this research were recent stories in various media regarding foreign workers in Slovenian economy and little to no research studies in the field of tourism. The idea of the article was to demonstrate the employment of labour migrants' experiences in tourism and to make proposals to improve the employment experience in the future. We started out by studying the existing theory, and then performed qualitative research, in which the employment experiences of four immigrants was studied in the previously mentioned four identified areas. Interviews were carried out with immigrants from different countries and of different professions, and were later evaluated with content analysis. The results of the study show that the employment experience of immigrants employed in tourism in Slovenia is both positive and negative, as there were positive and negative factors of experience identified in all areas of research. We do not want to give a generalised assessment of the experience, but rather show certain views and experiences; based on that, we can learn. The results do not apply to the entire population, but with them we present the diversity of the subject. The greatest limitation while researching was finding participants. Initially, proposals for improvement are given on three levels; government, employer, and society. The main improvement should be the better flow of information, for which we suggest transferring more information online. Slovene society should be striving for tolerance so that foreigners would feel more welcomed.

Keywords: tourism labour, immigrants, employment experience https://doi.org/10.26493/2335-4194.10.151-165

\section{Introduction}

After reading existing literature and previous foreign studies, we determined that the complete outlook on the experience of economic immigrants consisted of more separate but connected areas. This is how we came to our four main areas of research. Formal regu- 
lation is crucial for legal residence, which is necessary for employment and insurance. This is all connected with job satisfaction, normal dealing with health issues and, in the end, a peaceful life. Integration was added to our research, because it is tightly connected with general experience; for example: if we are accepted well, we feel good, and this is reflected in our health and job performance. This then leads to job satisfaction.

Jobs in tourism are less valued; employees often work at night and during holidays, wages are low and permanent contracts are a rarity (Joppe, 2012). Such work positions are less attractive to local populations, so employees are increasingly employing foreigners from economically less developed countries (Wood, 1992; Janta, Ladkin, Brown, \& Lugosi, 2011; Joppe, 2012). This research includes the economic or labour immigrant, who is an individual that leaves his place of residence to improve his quality of life (International Organization for Migrations, 2011).

In this research, we use the general term 'immigrant,' meaning economic immigrant, but not refugees. According to Hancova, Beehr, and Christiansen (2003), employment experience is adjustment to working conditions and to situations that are not workrelated but nevertheless occur in the life of an immigrant. Romzek (1989) warns that the employment experience can have consequences transmitted to life outside the workplace. Feng and Pearson (1999) also emphasise the importance of external factors, including new culture, language, economic situation, political situation, and family status, which are significant in the employment experience. This is the reason this research included not only work satisfaction, but also experience outside the workplace. This is how integration into the Slovenian environment was added to the research. Mathieu and Zajac (1990) assert that if the employee's experience is positive, it is assumed that he will work better, which then leads to economic benefits for the employer; there are also fewer absences from the workplace. In contrast, a negative employment experience results in low productivity, poor income, and is one reason for workers to quit their job.

According to Janta et al. (2011), positive experiences of immigrant workers can be language learn- ing, meeting new people, flexibility, and better wages. Negative experiences that these authors detected were hard work, tiredness, health problems, and little or no free time. Discrimination from management tends to be a frequent negative experience. As Lyon and Sulcova (2009) described, language barriers are a common negative experience, which is also noted in the work of Devine, Baum, Hearns, and Devine (2007). Irimias and Michalko (2016) stated that many immigrants lack proper living conditions.

Earlier research on employment the experience of immigrants working in tourism in Slovenia is difficult to find. Some authors studied topics on the working and living conditions of foreigners in Slovenia, mostly builders and drivers, but they do not discuss foreigners in tourism (Lipovec Čebron, 2010; Požar, 2010; Medica, Lukič \& Kralj, 2011; Oštir, 2012). The selected research topic is poorly covered or even uncharted territory in Slovenia, but not insignificant.

Exploring the positive and negative experiences was carried out in four topics, which, it is believed, are essential for complete outlook on the research matter; (1) formal regulation of working and living, (2) health and social care, (3) job satisfaction and (4) integration into the Slovenian environment.

\section{Immigrants in Slovenia}

Slovenia has, equivalent to Sweden, a multicultural/ pluralistic model of integration policy, which guarantees equal opportunities for all people living in the country, including immigrants (Bešter, 2003). By joining the European Union, Slovenia was awaiting highly educated individuals from other member states, but statistics show that these expectations have not been fulfilled. The majority of immigrants in Slovenia come from the territory of the former Yugoslavia and are not highly educated (Medica et al., 2011). Statistics show that the majority of immigrants are male and $50 \%$ of them in 2016 , had only lower or secondary vocational education. Data from the same year show that $55.7 \%$ of immigrants are settled in the Ljubljana region. In 2016, there were 16,993 issued permits, and they were mostly for positions in construction, whereas only $1.2 \%$ of them were in tourism. The majority of the permits issued in 2016 were for citizens of Bosnia and Herze- 
govina, Croatia, Serbia, and the Eu member state Bulgaria (see http://www.ess.gov.si/trg_dela/trg_dela_v _stevilkah/zaposlovanje_tujcev).

\section{Formal Regulation of Working and Living}

The field of immigrant legal work and residence in Slovenia is governed by various laws and regulations. On the 16th of June 2015, the National Assembly of the Republic of Slovenia adopted the Employment, SelfEmployment and Work of Foreigners Act' which entered into force on the 1st of September 2015. Under the new legislation, only one permit is issued to foreigners, which controls both employment and residence (under previous legislation, they needed separate permits). The new act means fewer bureaucratic obstacles, and it also costs less due to the payment of a single fee (Zakon o zaposlovanju, samozaposlovanju in delu tujcev (ZZSDT), 2015).

The employment of citizens of the Republic of Croatia is regulated by the Act Extending the Transitional Period for Free Movement of Citizens of the Republic of Croatia and Their Family Members (Zakon o podaljšanju prehodnega obdobja na področju prostega gibanja državljanov Republike Hrvaške in njihovih družinskih članov (Z P P O P G HR), 2015) It stipulates that those citizens of the Republic of Croatia who have been legally residing in Slovenia for at least two years have free access to the labour market, which equates them with citizens of Slovenia. Free access to the labour market also includes the Croats of Slovenian descent to the second generation, those who have a permanent residence permit in Slovenia, family members of an immigrant who reside in Slovenia with an intention for family reunion and Croats who acquired at least higher education or were engaged in research work in the previous two years. Those who reside in Slovenia less than two years need a work permit issued by the Employment Service of Slovenia.

On the basis of the 'Agreement on the Employment of Citizens of Bosnia and Herzegovina in Slovenia,' such citizens are issued a work permit, which is an addition to the previously mentioned single permit. The content of agreement specifies the conditions for the employment of foreigners from the Bosnia and Herzegovina (see http://www.ess.gov.si/tujci/delo_v _sloveniji/zaposlovanje-drzavljanov-bih). The statistics on the 31st of December 2016, which show the ratio of foreigners from third countries (i.e. those not in the $\mathrm{EU}$ ) in Slovenia, disclose that the majority of immigrants with a valid residence permit is from Bosnia and Herzegovina $(58,355$ valid permits), followed by immigrants from Kosovo, Serbia, Macedonia and the Russian Federation (see http://www.mnz.gov.si/si/mnz _za_vas/tujci_v_sloveniji/statistika/).

\section{Health and Social Care}

The untroubled stay of immigrants in foreign countries is essentially conditioned by regulated health and social care, which are a basic human right. In the countries of the European Union, foreigners from third countries have the same rights as residents (Trokić, 2006), which means that employed or self-employed immigrants are equal to the citizens of Slovenia. This status can also be enjoyed by the immigrant's family with a residence permit (Ministrstvo za delo, družino, socialne zadeve in enake možnosti, 2010). Irrespective of the status of insurance, emergency medical assistance is available to all, with payment provided from public resources (Cetina \& Pokrivač, 2014). Bofulin and Bešter (2010) observe that, according to research in Europe, economic immigrants are healthier than residents. There is, however, a grey area: despite health problems, immigrants do not visit healthcare institutions; the reasons for this are numerous: they are employed in the grey economy, are faced with a lack of finances for the payment of services, have language barriers to communicate with medical staff, do not trust other health systems, or find themselves in a discriminatory relationship with healthcare professionals. Despite formal equality, marginalised groups generally have less access to healthcare. The research carried out by Brovč, Ahčin, Šlajpah, and Rotar Pavlič (2009) shows that immigrants ascribe their health problems to poor housing conditions, diet, poor working conditions, hard work, and strong negative emotions such as fear, anger and nervousness. Immigrants are, to a greater extent, also exposed to mental health problems due to the new environment and the resulting stress. The authors emphasise the fact that immigrants also have communication problems with healthcare pro- 
fessionals. In this area, it is possible to improve and simplify the immigrant's stay in Slovenia. Lipovec Čebron (2010) further notes a general lack of information on health rights among immigrants.

\section{Job Satisfaction}

Job satisfaction is interpreted as a positive emotional reaction that the worker perceives when engaging in work (Zupan, 2001). Dugguh and Dennis (2014) continue, that to achieve good results, the company must strive for employees to be motivated and satisfied with their work. Satisfaction is positively influenced by payment, working conditions, relationships with colleagues and superiors and the prospect of promotion, which was also researched in the work presented in this paper. There are several theories of satisfaction at work. One of the best known is Herzberg's two-factor motivational theory from 1959, which deals with what makes employees pleased. Lundberg, Gudmundson, and Andersson (2009) uncover that Herzberg's theory is based on motivating factors and hygiene factors. Hygiene factors are those which must be guaranteed; otherwise, the worker is dissatisfied. This includes company policies, supervision, payment, working conditions, and social relationships in the company. In contrast, motivating factors, such as recognition for good work, work itself, independence, the level of responsibility in the workplace that is entrusted to the worker, promotion and other achievements are those that bring satisfaction. The authors explain Herzberg's thesis ass stating that the opposite of satisfaction is not dissatisfaction: it is only the absence of satisfaction. In practice, this means that if the motivators are not provided, workers are not dissatisfied. They are dissatisfied when hygiene factors are not provided.

An immigrant employed in Slovenia has equal rights to those of native employees. These rights include frequent payment, food, and transport bonuses, and annual leave (Zakon o zaposlovanju, samozaposlovanju in delu tujcev (ZZSDT), 2015). Job satisfaction is connected to many factors, including the sense of safety and health at work, which are important for employees and significantly affect their wellbeing. In Slovenia, this is regulated by the Occupational Health and Safety Act (Zakon o varnosti in zdravju pri delu (zVZD-1), 2011), which lists technical, legal, educational, social, and health measures to create a safe workplace. Oštir (2012) finds that that most common anomaly in the work of immigrants is illegal work, in which the employer does not pay obligatory contributions to the state. Attention is also given to the fact that the wages of immigrants are lower, and even lower for female immigrants, and that there are many 'cash in hand' payments, which once more shows that social contributions are not paid. It is often the case that workers are waiting for payment even after several months. In reviews of literature and previous studies (Medica et al., 2011; Oštir, 2012; Zabukovec, 2015), the fact that employees work without appropriate work equipment and protection was detected. The aforementioned authors noted, that foreign workers are more likely to work in shifts, during weekends, have more additional hours and less annual leave and, because of the employer's pressures, they do not take sick leave. There are many violations regarding the allocation of working time. Nevertheless, migrants can be a source of innovative ideas for a business, and they represent cultural diversity. This diversity can also lead to tensions, which is what happens if employers do not promote interaction between domestic and foreign employees, and if foreigners do not adapt to the culture of the host country (Janta, Brown, Lugosi, \& Ladkin, 2011).

\section{Integration}

When people immigrate to a different environment, two diverse cultures come into contact. Vrečar (2007) even claims that there is a contact of many cultures at the same time, in which the culture of the destination is labelled as dominant, and others subordinate. Despite the laws, regulations, strategies, and other documents that control the topic, the integration of immigrants remains a complex phenomenon. According to the author, the level of integration is affected by conditions in the country of origin, the possibility of longterm adaptation, the existence of social networks, the personality characteristics of the immigrant, and the phenomena of xenophobia and racism. Immigrants find themselves in a new cultural framework in which they introduce new ethnic peculiarities into the dom- 
inant culture, which is why discrimination in the history of migration is discussed. Bešter (2007) describes integration as the process of the inclusion of foreigners in a new environment and the resulting effects. There is both complete assimilation or extreme multiculturalism, according to which integration differs in the fact that both immigrants and the majority culture adapt. Integration is a complex phenomenon that must or may occur in several areas. As presented below, areas 1-3 are common for any type of immigrant, areas 4-7 are more about long-term immigrants (Bešter, 2007):

1. Legal integration; equalising the legal status of an immigrant with a citizen of the Republic of Slovenia. It begins with a residence permit and a work permit, with the enabling of social rights and equalisation with the acquisition of citizenship. It is a key aspect of integration.

2. Settlement and housing integration; allows foreigners to stay anywhere in the country (region, city) and live in comparable, even identical living conditions, and have the possibility of moving.

3. Socio-economic integration; employment opportunities, social rights, and comparable income.

4. Integration in education (especially for the second generation of immigrants); foreigners should have the same educational opportunities and achieve a certain level of education. Multicultural education in schools and the possibility to learn one's native language are important.

5. Cultural integration; it covers language, religion and new values. The acceptance of new patterns and values is of great importance, but the aim of cultural integration should not be complete assimilation, since we must allow foreigners to maintain their own culture.

6. Social integration; involves social integration in the surroundings and socialising with individuals. If foreigners maintain contact only within one ethnic group, this cannot be considered integration.

7. Identification integration; an individual's perception of belonging to a new culture.

\section{Research Methodology}

The purpose of the research was to obtain information about the employment experience of immigrants working in tourism in Slovenia and complement the data with the new findings. Findings are useful for businesses in the field of tourism, organisations that work with immigrants, but not likely also for immigrants. The aim was to answer the main research question (QO) and questions related to the four previously identified topics (Q1-4).

QO What is the employment experience of immigrants employed in tourism in Slovenia?

Q1 What is the experience of immigrants employed in Slovenian tourism in the formal regulation of work and living?

Q2 What is the experience of immigrants employed in Slovenian tourism, in the field of health and social care?

Q3 What is the experience of immigrants employed in Slovenian tourism regarding job satisfaction?

Q4 What is the experience of immigrants employed in Slovenian tourism, in the field of integration into the Slovenian environment?

The first stage of work included an overview of primary and secondary sources (Devine et al., 2007; Janta et al., 2011; Zopiatis, Constanti \& Theocharous, 2014), which were the foundation for creating four theoretical research categories, as previously mentioned. This makes the research deductive. In consultation, interviews were chosen over questionnaires, due to the potentially low response rate. Silverman (1993) states that qualitative or interpretive research enables deeper exploration of the desired topic, and attention is drawn to the experience of the participants. The researcher's involvement in the interview was limited to guiding the conversation with minimal impact on the content of it, thereby ensuring greater objectivity of the data.

The research sample consisted of immigrants employed in tourism in Slovenia. Theoretical sampling was chosen, and immigrants were invited to participate via organisations, companies, and social media. The first draft of this research consisted of data to be 
Table 1 Profiles of Participating Immigrants

\begin{tabular}{llllll}
\hline Interview & Age & Sex & Country & Time in Slovenia & Work position \\
\hline 1 & 27 & Female & Bosnia and Hercegovina & 7 years & Hotel marketing \\
2 & 28 & Male & Montenegro & 7 years & Night reception in hotel \\
3 & 38 & Male & Tunisia & 8 years & Waiter in hotel \\
4 & 31 & Female & Serbia & 6 months & Housekeeping \\
\hline
\end{tabular}

collected with surveys, and the set sample was approximately 70 people. After several months, the idea was dropped due to a very low response rate. Interviews were chosen.

Four interviews with immigrants of different nationalities, professions, and ages (as shown in Table 1) were performed from January 2016 to September 2016. Research limitations are reflected in the difficult acquisition of participants. It is noted that immigrants or employers do not wish to reveal themselves, even though the participation was anonymous. The research would have shown the situation in greater detail with more participants of different profiles.

Content analysis was the method chosen for data analysis. The process consisted of the transcription and editing the recorded interviews, including the translation of one interview, which was held in Serbian. Later, with a partially deductive approach, the data were broken down to four selected categories (formal regulation of working and living, health and social care, job satisfaction and integration into the Slovenian environment) and collections of related topics within these categories, which became subcategories. Data analysis has identified factors and divided them according to whether they were positive or negative. The results do not apply to the entire population, but we present the diversity of the subjects with them. We wanted to portray certain views of employment in the tourism industry in Slovenia.

\section{Results and Discussion}

Interviews were analysed by identifying subcategories and factors according to a positive or negative experience. Results were placed in tables for individual areas of research, as shown in Tables 2 to 5 . The deductive elements of the analysis are the basic categories of the experience. We identified subcategories and fac- tors inductively, which are characteristics of work experience. Two participants took up employment in Slovenia after completing their studies in Slovenia, a participant from Tunisia came to Slovenia as a family member, as a spouse to a Slovenian, and the fourth participant came to Slovenia due to unemployment in his home country, despite college education.

\section{Formal Regulation of Working and Living}

Throughout the analysis of the interviews, the positive and negative experiences of immigrants in the formal arrangements of working and living were identified, as shown in Table 2. Identified subcategories were about procedures of acquisition and the attitude of officials.

The work permits category lists positive experiences. For example, one immigrant had no problem acquiring the permits based on the fact that her family had stayed in Slovenia for a longer period. Another had fewer problems due to dual citizenship.

It was easy for me because I have dual citizenship, Croatian and Serbian, because I was born in Croatia. So, I came to Slovenia with Croatian papers, due to Croatia also being in the $\mathrm{EU}$. For my boyfriend, who has only Serbian documents, the process was much more difficult. [Housekeeper, Serbia]

They are furthermore pleased with the acquisition process itself. Negative factors are understanding procedures due to language barriers, which Lyon and Sulcova (2009) also noted to be one of the greatest limitations. Another negative aspect is the time required for the process.

There were no problems, but the procedure by law lasts a few months. I needed a month for a 
Table 2 Analysis of Formal Regulation of Working and Living

\begin{tabular}{|c|c|c|c|}
\hline \multirow[t]{2}{*}{ Category } & \multirow[t]{2}{*}{ Subcategory } & \multicolumn{2}{|l|}{ Experience } \\
\hline & & Dimension & Factor \\
\hline \multirow[t]{9}{*}{ Work permits } & Procedure & Positive & Long-term stay in Slovenia \\
\hline & & & Family member status \\
\hline & & & Dual Citizenship \\
\hline & & Negative & End of student status \\
\hline & & & Not understanding procedures \\
\hline & & & Duration of acquisition \\
\hline & Officials & Positive & 1 \\
\hline & & Negative & Poor attitude \\
\hline & & & Language barriers \\
\hline \multirow[t]{4}{*}{ Residence permits } & Procedure & Positive & No problems \\
\hline & & Negative & No work permit \\
\hline & & & $\begin{array}{l}\text { Acquisition system does not divide those who integrate } \\
\text { more and those who integrate less }\end{array}$ \\
\hline & & & Duration \\
\hline
\end{tabular}

residence permit and three months for a work permit. [Waiter, Tunisia]

Immigrants mention the problem of misunderstanding procedures, due to language and not knowing the laws and regulations and inadequate experience with officials. By doing so, the immigrant finds that the law and officials equate those who are trying to adapt and those who do not.

The worst experience was with the administrative office in Koper when I wanted to get a residence permit. [Night receptionist at a hotel, Montenegro]

The immigrants talked about procedures for acquiring residence permits. Some had no problems, while one mentioned he could not get a permit, because his student status in Slovenia had ended and, consequently, he had no permission for work. He solved the problem by registering as a family member with a girlfriends' family. This is not a negative experience, but one critique of the system is the fact that it does not distinguish between those who integrate more and those who do not.
The law and the staff of office treat those, who are trying to engage in society and those who do not bother the same. [Night receptionist at a hotel, Montenegro]

All participants have work and residence permits, but it is clear from the above that they had few difficulties obtaining them, which nevertheless could be improved at the state level.

\section{Health and Social Care}

The participants were asked about their experiences with health and social care in Slovenia. From the preliminary examination of the literature, it is understood that in Slovenia the greatest problems are in the poor health status of immigrants, which is the result of an unhealthy work environment, stress and other negative feelings (Brovč et al., 2009). We attempted to determine whether our immigrants felt this reflected their experiences. In the majority, they have good experiences with health and social care, but there are some improvements that could be made.

In the area of healthcare, two subcategories were detected; the system, and the experiences with it or with medical staff. Positive feelings were noted about 
Table 3 Analysis of Health and Social Care

\begin{tabular}{|c|c|c|c|}
\hline \multirow[t]{2}{*}{ Category } & \multirow[t]{2}{*}{ Subcategory } & \multicolumn{2}{|l|}{ Experience } \\
\hline & & Dimension & Factor \\
\hline \multirow[t]{6}{*}{ Health care } & System & Positive & Through the employer \\
\hline & & Negative & Fear of unpaid contributions by employer \\
\hline & Experience & Positive & Friendliness \\
\hline & & & Sick leave \\
\hline & & Negative & Doctors attitude \\
\hline & & & Unselected doctor \\
\hline \multirow[t]{5}{*}{ Social care } & Experience & Positive & Better than at home \\
\hline & & & Enough for survival \\
\hline & & Negative & / \\
\hline & Information & Positive & / \\
\hline & & Negative & Not knowing rights \\
\hline
\end{tabular}

the fact that basic health insurance is paid by the employer, but one of the participants feared that the same contributions would not be paid. In the area of experience with healthcare, positive experiences included the friendliness of medical staff and the possibility of having sick leave when needed. Negative experiences included the medical staff's attitude in one case.

I had problems with my lower back and I went to the doctor, she looked at me and gave me the wrong medicine, which made me pass out. She did not give me medicine that would soothe inflammation, but medicines to relax my body. I cannot know for certain, but obviously she did not take much time to deal with me. [Night receptionist at the hotel, Montenegro]

The next negative experience was problems with having no assigned personal doctor. Immigrants say that social care in Slovenia is better than in their home country, and they believe Slovenia would help them if needed.

If I compare it with my country, social care is definitely much better regulated. I know that Slovenia would help me. [Employed in marketing, Bosnia and Herzegovina]

Negative experiences in the category of social care are mainly due to the immigrants not knowing their rights. As Trokić (2006) says, foreigners working and living in Slovenia have the same rights as locals. The author emphasises that these rights are not only for physical help, but also for psychosocial assistance.

The experience of social protection is highly positive, as the participating immigrants in Slovenia feel safe.

\section{Job Satisfaction}

The employment experience of an immigrant employed in Slovenian tourism is largely influenced by job satisfaction. Immigrants were asked about general satisfaction, work relationships, payment, meals, working hours, and other working conditions. The participants answered the questions without reservation. Immigrants responded positively to the question of general job experience and job satisfaction.

Yes, I am content, otherwise I would not be working in the same company for eight years. [Waiter, Tunisia]

I'm currently working as a maid in a hotel and I am doing fine. I want a better job, but for the beginning it is quite good and I'm happy. [Housekeeper, Serbia]

The qualitative analysis of the interviews identified 
Table 4 Analysis of Job Satisfaction

\begin{tabular}{|c|c|c|c|}
\hline \multirow[t]{2}{*}{ Category } & \multirow[t]{2}{*}{ Subcategory } & \multicolumn{2}{|l|}{ Experience } \\
\hline & & Dimension & Factor \\
\hline \multirow[t]{8}{*}{ Work conditions } & Work time & Positive & Statutory framework \\
\hline & & & Use of leave \\
\hline & & Negative & Night work \\
\hline & & & Extra hours \\
\hline & & & Free days \\
\hline & Meals & Positive & Meal at work \\
\hline & & & Possibility of cash compensation \\
\hline & & Negative & I \\
\hline \multirow{9}{*}{$\begin{array}{l}\text { Workplace } \\
\text { Relationship }\end{array}$} & Employer & Positive & Foreign company \\
\hline & & & Promotion \\
\hline & & & Attitude \\
\hline & & Negative & l \\
\hline & Peers & Positive & Acceptance \\
\hline & & & The nature of work \\
\hline & & Negative & Feeling neglected \\
\hline & Customers/guests & Positive & Foreign language \\
\hline & & Negative & Strange attitude \\
\hline \multirow[t]{6}{*}{ Payment } & & Positive & Raise \\
\hline & & & Paid extra hours \\
\hline & & & Benefits \\
\hline & & & Tips \\
\hline & & & Regularity \\
\hline & & Negative & Amount \\
\hline
\end{tabular}

areas of positive and negative experiences, as shown in Table 4.

Subcategories identified within work conditions were working hours and meals. One positive experience was that all the immigrants work in this study within the legal framework. In the Employment Relationship Act (Zakon o delovnih razmerjih (ZDR-1), 2013) it is defined that the work week consists of 40 hours and a maximum of eight extra hours. Immigrants can also use their annual leave with no problems. Negative feelings were about night work, working hours and extra hours, also with having no free days in a week. This was the experience of a hotel night receptionist; the authors of this research believe that this dissatisfaction is not connected with the worker being an immigrant. Nevertheless, he felt unhappy.

There is not enough staff, and it often happens that I do not have one day off during the week. If someone gets sick, there is no substitute worker. [Night receptionist at a hotel, Montenegro]

They are satisfied with having meals arranged during work hours, and they even have the possibility of compensation if they have a prescribed special diet. Workplace relations were divided in three subcategories: relationships with employer/superior, with peers, and with customers. All the immigrants had good relationship with their superiors. One said that 
she works for foreign company; since employer is foreign, a foreign worker does not stand out.

The company is also foreign, so there are no problems with discrimination in the workplace. [Employed in marketing, Bosnia and Herzegovina]

Because of the good relationships, they had opportunities for promotion. With their peers, they mostly felt accepted, also because of the nature of tourism. As the World Tourism Organization (2014) states, tourism is a dynamic sector, characterised by everyday contact with people. Employment is also available for young, inexperienced workers, poorly educated people, and people of different cultures and races. However, one participant did not feel accepted, which she believed was because of language barriers.

I am left out of socialising with colleagues, mostly because of the language, sometimes I feel lonely. [Housekeeper, Serbia]

With customers, they did not have particularly negative experiences; only one of them felt that guests treated them differently than their Slovene peers did. Otherwise, they say guests are interested in their stories of how and why they came to Slovenia.

Payment was the next topic of discussion. The only negative feeling given was regarding the amount of salary. Joppe (2012) and Baum (2015) confirm that jobs in tourism are not paid well. Positive feelings were reflected in the possibility of a raise, in some cases paid extra hours and benefits such as a bonus for work clothes. Three of the four participants also work for tips.

\section{Integration into the Slovenian Environment}

For the well-being and positive employment experience of immigrants in Slovenia, integration into the new environment is also important. During the discussion, immigrants confided their experiences about living conditions, language, free time, discrimination and integration, shown in Table 5.

The first category was residence with the subcategories of living conditions and the process of searching for accommodation. In the first subcategory, positive factors were that they live in good conditions and they live with family or a partner. One immigrant was living with roommates during his studies, and he says the experience was pleasant, mostly because they helped him integrate better and faster. Immigrants mentioned some negative experiences regarding the search for accommodation. Some encountered discrimination or lack of trust by the owner of the apartment.

The owners said they did not accept foreigners. They emphasised that they did not accept Albanians or Muslims. [Night receptionist at a hotel, Montenegro]

They were a little suspicious. How we will pay, how long will we stay, but this is normal to me, we gave them employment certificates and a prepayment and that's it. Now we are paying rent, and everything is good, we have a fair relationship with the landlord. [Housekeeper, Serbia]

As Lukšič-Hacin (1995, p. 111) states, when people change their cultural and social environments, language is one of the fundamental obstacles to integrating and understanding the way of life in a new environment. Participants do understand that language helps with integration. However, they were having some initial problems, which is, in the authors' opinion, normal. One of the participants had difficulties with formal communication when working.

The problem arises with e-mails when you want to write more formally, but I think a lot of Slovenians have the same problem [smiles]. [Employed in marketing, Bosnia and Herzegovina]

They learned language during informal communication with locals, and some took classes and exams. This shows that they were eager to learn and integrate. The immigrant from Serbia expressed personal dissatisfaction due to poor language skills. At the time of the interview, she had been in Slovenia only for six months.

Participants use their leisure time differently, de- 
Table 5 Analysis of Integration into the Slovenian Environment

\begin{tabular}{|c|c|c|c|}
\hline \multirow[t]{2}{*}{ Category } & \multirow[t]{2}{*}{ Subcategory } & \multicolumn{2}{|l|}{ Experience } \\
\hline & & Dimension & Factor \\
\hline \multirow[t]{6}{*}{ Residence } & \multirow[t]{3}{*}{ Conditions } & Positive & Good infrastructure \\
\hline & & & Roommates \\
\hline & & Negative & I \\
\hline & \multirow{3}{*}{$\begin{array}{l}\text { Search for ac- } \\
\text { commodation }\end{array}$} & Positive & I \\
\hline & & Negative & Discrimination \\
\hline & & & No trust \\
\hline \multirow[t]{7}{*}{ Language } & \multirow[t]{3}{*}{ Knowledge } & Positive & Better integration \\
\hline & & Negative & Formal communication \\
\hline & & & Initial problems \\
\hline & \multirow[t]{4}{*}{ Learning } & Positive & Communication with locals \\
\hline & & & Courses \\
\hline & & & Exam \\
\hline & & Negative & Dissatisfaction due to not knowing language \\
\hline \multirow[t]{9}{*}{ Free time } & \multirow[t]{5}{*}{ Social network } & Positive & Help from locals \\
\hline & & & Getting to know the culture \\
\hline & & & Locals \\
\hline & & & Contact with other foreigners \\
\hline & & Negative & Locals \\
\hline & \multirow{4}{*}{$\begin{array}{l}\text { Activities for } \\
\text { foreigners }\end{array}$} & Positive & Participation \\
\hline & & & Quality \\
\hline & & Negative & Lack of free time \\
\hline & & & No interest \\
\hline \multirow[t]{5}{*}{ Discrimination } & & Positive & Younger generation \\
\hline & & & Islamic community \\
\hline & & Negative & Eating habits \\
\hline & & & Stereotypes \\
\hline & & & Search for accommodation \\
\hline \multirow[t]{2}{*}{ Integration } & \multirow[t]{2}{*}{ Holidays } & Positive & Open society \\
\hline & & Negative & Celebration \\
\hline
\end{tabular}

pending on their interests and desires. When researching their free time, the most frequent topics were about their social network and activities organised for foreigners. Positive experiences they had within their social network were getting help from locals and in some cases acceptance by the local population.

They always helped me. I met good and hard- working people, especially friends who helped me, to get to where I am right now. [Employed in marketing, Bosnia and Herzegovina]

One was happy that she could spend her free time with other foreigners. In her opinion, it was easier to discuss problems with people who have or had the same experiences. Some had negative experiences 
with locals. This shows that different people react differently to foreigners. The immigrant from Montenegro was happy with the activities organised for foreigners in Slovenia.

I was invited by the Montenegrin ambassador in Ljubljana, to meet Montenegrin students and Montenegrins living in Slovenia. I attended, and it was a nice experience. [...] I also attended one round table event at the university, on the topic of integration of immigrants. Nice experience at a high educational level. [Night receptionist at the hotel, Montenegro]

Others explained that they do not have free time or interest to participate. With this, we can conclude that while there are good events and workshops, but immigrants are not keen to participate. Regarding discrimination, positive feelings were expressed when speaking of the younger generation in Slovenia, which is more open to new things than the older generation is. One participant, a Muslim, praised the Muslim community in Slovenia. Immigrants who participated in the survey did not have major negative experiences with discrimination. We were primarily interested in religious and national discrimination. They highlighted only a few experiences concerning stereotypes and irritations due to different dietary habits and the aforementioned difficult experience in finding a suitable dwelling place.

I know another Tunisian who lives and works in Maribor. He's darker than I am and he has more problems. [Waiter, Tunisia]

Another topic that has been identified in the field of integration is culture, or more precisely celebrating holidays. The immigrants talked about accepting Slovenian traditions and the possibility of celebrating their holidays.

An interesting indicator of the experience of being an immigrant is the plans that they have. One participant aspires to create a life in Slovenia; another, because of the wars and terrorist threat, does not want to return to Tunisia. Despite the positive experience in Slovenia, two participants want to move to another country with the aim of new knowledge and experience.

\section{Conclusion}

The presented research has theoretical and practical value. The theoretical value lies in the identification of different dimensions of the employment experience of immigrants working in tourism in Slovenia, which contributes to the knowledge about that field. With this, future researchers can easily assess what is important to research and what the critical points are. The practical value of the work is reflected in the proposals for improvements. The aim of the presented research was to answer the research questions.

The first research question was: 'What is the experience of immigrants employed in Slovenian tourism in the formal regulation of work and living?' All four immigrants have permits and are now satisfied. There were some good experiences, which is reflected in the fact that they got their permits. Many negative factors are reflected in the difficulties they had in requiring them. They had problems with language, the attitudes of officials, and the duration of the process. The experiences of immigrants employed in Slovenian tourism in the formal regulation of work and living were both positive and negative. To summarise, they believe the experience was good, because it resulted in them having a legal status in Slovenia, but the process itself could be easier.

The second research question was: 'What is the experience of immigrants employed in Slovenian tourism, in the field of health and social care?' It was found that each immigrant had different opinions and varied experiences. They are happy they have insurance covered by their employer, but at the same time they fear that they would not be paid. They have good and bad experiences with medical staff. Use of sick leave was highly valued by four of them. More positive feedback was given regarding social care, with immigrants saying that they feel safe in Slovenia. The negative aspect is the lack of information in both areas. Experiences are positive and negative; however, it is observable they are more satisfied with social care. Although they are happy with healthcare benefits, some real-time experi- 
ences were negative; meanwhile, none of the four had needed to use social care and, therefore, have no practical experiences with this.

With the third theoretical research question, 'What is the experience of immigrants employed in Slovenian tourism regarding job satisfaction?' discussion about work experiences was opened. Immigrants are happy with their work conditions; their only negative factors were night work, extra hours and lack of free days. These are common in tourism and are not the result of a different treatment due to their being foreign. Experience with meals during work are only positive. Discussion about work relationships showed that they have only positive feelings regarding relationships with their employer or superior and mostly good experience with co-workers. Only one did not feel included. From customers, they mostly received positive attention. With common negative feelings about the amount of salary, they were happy with getting tips, bonuses; some were also able to have extra paid hours. This dimension shows mostly positive experiences and some negative, but it is believed they are not crucial.

The fourth and final research question was: 'What is the experience of immigrants employed in Slovenian tourism, in the field of integration into the Slovenian environment?' Three participants were highly integrated, due to longer periods of stay in Slovenia. The Serbian immigrant had been, at the time of the interview, in Slovenia for only six months. Her answers were more negative, especially regarding language and local acceptance, than those of other participants. They were all satisfied with their living conditions, although there were some problems with finding a suitable place to live. In the category of language skills, negative feelings were detected, when they talked about their start in Slovenia. Regarding their social network, the main topic was connecting with locals, for which the experience was positive in most cases, especially with the younger generation. Participants did not detect severe discrimination: only some stereotypes. They say Slovene society is somewhat open to new culture differences and does accept foreign habits, but they feel sad that they cannot celebrate holidays as at home. Discussions showed that there were some negative experiences among the good ones. The local population still have some reservations towards new things. The results confirm the theory that the more integrated foreigners have better experiences.

Answering the four questions regarding the selected dimensions leads to answering the main research question: 'What is the employment experience of immigrants employed in tourism in Slovenia?' The study results show that experiences in all four studied areas (formal regulation of working and living, health and social care, job satisfaction and integration into the Slovenian environment) are positive and negative. Participants' answers and stories show that they are content with working and living in Slovenia. However, the discussion pointed out some negative experiences, which can be a basis for improvement.

The purpose of this research was to outline the immigrants' experience and consequently improve it. Improvements can be made at the level of the state, industry and society, which should better accept foreigners in their environment. A key improvement, identified by the fact that immigrants are not well informed about administrative processes, social assistance and their rights, is the better flow of information. Some brochures are available at administrative offices, employment offices and even online, but it is noted that they rarely are accessed by foreigners or they contain outdated information. It would be reasonable for the information to be transmitted over the web and social networks to a greater extent, and the employees of the administrative units should personally hand over information packets to the immigrants and not only put them on info boards. By improving the flow of information, progress would be made in the areas of ignorance of the system and rights, misunderstanding of procedures, promoting the choice of a personal medical doctor, attending events for foreigners and promoting language courses.

To prevent the fear of non-payment of social contributions by the employer, immigrants should also be informed about the methods of checking those payments and the possibilities of anonymous reporting to the Financial Bureau of the Republic of Slovenia. Because of the negative experiences about relations with 
the local population, relations with healthcare personnel and others, it is important that multiculturalism is promoted within Slovene society through various integration programs and volunteering. In this area, particular emphasis is placed on pre-school and school institutions, which are supposed to teach tolerance and reduce the social distance to foreigners, as described by Kralj (2008). It is also necessary to emphasise the positive factors highlighted by the interviewees, which should serve as examples of good practice. With this kind of promotion and information, it would make it easier for future immigrants to decide to come to Slovenia, encourage employers to employ foreigners and, in particular, show the positive side of the existence of foreigners in Slovenia to the local population (for example: cultural diversity, new workforce, and fresh ideas).

The results do not apply universally; with these results, we only highlight the diversity of the research topic, which now serves as a basis for future research. One plan is a quantitative study of the employment experiences of immigrants in tourism with a larger sample. Despite the limitations and obstacles, the research has been successful, as it presents the experience of immigrants employed in tourism in Slovenia and answered research questions.

\section{References}

Baum, T. (2015). Human resources in tourism: Still waiting for change? A 2015 reprise. Tourism Management, 50, 204-212.

Bešter, R. (2003). Migracijska politika Slovenije in EU: primerjava zakonodaje. Ljubljana, Slovenia: Mirovni inštitut.

Bešter, R. (2007). Integracija in model integracijske politike. In M. Komac (Ed.), Priseljenci: študije o priseljevanju in vključevanju v slovensko družbo (pp. 105-134). Ljubljana, Slovenia: Inštitut za narodnostna vprašanja.

Bofulin, M., \& Bešter, R. (2010). Enako zdravstvo za vse? Imigranti v slovenskem zdravstvenem sistemu. In M. Medvešek \& R. Bešter (Ed.), Državljani tretjih držav ali tretjerazredni državljani? Integracija državljanov tretjih držav v Sloveniji (pp. 270-311). Ljubljana, Slovenia: Inštitut za narodnostna vprašanja.

Brovč, M., Ahčin, J., Šlajpah, M., \& Rotar Pavlič, D. (2009). Ekonomski imigranti v Sloveniji in njihova stališča o boleznih - kvalitativna raziskava. Zdravstveno varstvo, 48(1), 26-32.
Cetina, I., \& Pokrivač, D. (2014). Vključevanje v slovensko družbo: informacije za tujce. Ljubljana, Slovenia: Ministrstvo za notranje zadeve Republike Slovenije.

Devine, F., Baum, T., Hearns, N., \& Devine, A. (2007). Cultural diversity in hospitality work: The Northern Ireland experience. The International Journal of Human Resource Management, 18(2), 333-349.

Dugguh, S. I., \& Dennis, A. (2014). Job satisfaction theories: Traceability to employee performance in organizations. Journal of Business and Management, 16(5), 11-18.

Feng, F., \& Pearson, T. E. (1999). Hotel expatriate managers in China: Selection criteria, important skills and knowledge, repatriation concerns, and causes of failure. Hospitality Management, 18, 309-321.

Hancova, R., Beehr, T. A., \& Christiansen, N. D. (2003). Antecedents and consequences of employees adjustment to overseas assigment: A meta-analytic review. Applied Psychology on International Review, 52(2), 213-236.

International Organization for Migrations. (2011). Glossary on Migration. International Migration Law, No. 25.

Irimias, A., \& Michalko, G. (2016). Hosting while being hosted: A perspective of Hungarian migrant hospitality workers in London, uk. Tourism and Hospitality Research, 16(2), 172-183.

Janta, H., Brown, L., Lugosi, P., \& Ladkin, A. (2011). Migrant relationships and tourism employment. Annals of Tourism Research, 38(4), 1322-1343.

Janta, H., Ladkin, A., Brown, L., \& Lugosi, P. (2011). Employment experiences of Polish migrant workers in the $\mathrm{UK}$ hospitality sector. Tourism Management, 32(5), 10061019.

Joppe, M. (2012). Migrant workers: Challenges and opportunities in addressing tourism labour shortages. Tourism Management, 33(3), 662-671.

Kralj, A. (2008). Nepovabljeni: globalizacija, nacionalizem in migracije. Koper, Slovenia: Annales.

Lipovec Čebron, U. (2010). Slepa pega evropskega zdravstva. In K. Medica, G. Lukić, \& M. Bufon (Ed.), Migranti v Sloveniji - med integracijo in alienacijo (pp. 57-81). Koper, Slovenia: Annales.

Lukšič-Hacin, M. (1995). Ko tujina postane dom: resonalizacija in narodna identiteta pri slovenskih izseljencih. Ljubljana, Slovenia: Znanstveno in publicistično središče.

Lundberg, C., Gudmundson, A., \& Andersson, T. D. (2009). Herzberg's Two Factor theory of work motivation tested empirically on seasonal workers in hospitality and tourism. Tourism Management, 3o(6), 890-899.

Lyon, A., \& Sulcova, D. (2009). Hotel employer's perceptions of employing eastern european workers: A case study of 
Cheshire, U K. Tourism, Culture \& Communication, 9(11), 17-28.

Mathieu, J. E., \& Zajac, D. M. (1990). A review and metaanalysis of the antecedents, correlates and consequences of organizational commitment. Psychological Bulletin, 108(2), 171-194.

Medica, K., Lukić, G., \& Kralj, A. (2011). Delovne in življenjske razmere delavcev migrantov $v$ Sloveniji (Report). Znanstveno-raziskovalno središče Koper, Koper, Slovenia.

Ministrstvo za delo, družino, socialne zadeve in enake možnosti. (2010). Strategija ekonomskih migracij za obdobje od 2010 do 2020. Retrieved from http://www.mddsz.gov .si/fileadmin/mddsz.gov.si/pageuploads/dokumenti __pdf/Strategija_ekonomskih_migracij-2010-2020.pdf

Oštir, N. (2012). Tujec na delu v Sloveniji: delovne in življenjske razmere delavcev migrantov $v$ Posavju (Unpublished diploma thesis). University of Ljubljana, Ljubljana, Slovenia.

Požar, U. (2010). Težave delavcev migrantov v Sloveniji (Unpublished diploma thesis). University of Primorska, Koper, Slovenia.

Romzek, B. S. (1989). Personal consequences of employee commitment. Academy of Management Journal, 32(3), 649-661.

Silverman, D. (1993). Interpreting qualitative data: Methods for analyzing talk, text and interaction. London, England: Sage.

Trokić, S. (2006). Regionalna integracija imigrantov $v E U$ (Unpublished diploma thesis). University of Ljubljana, Ljubljana, Slovenia.
Vrečar, N. (2007). Integracija kot človekova pravica: prisilni priseljenci iz Bosne in Hercegovine v Sloveniji. Ljubljana, Slovenia: Inštitut za slovensko izseljenstvo ZRC SAZU.

Wood, R. C. (1992). Working in hotels and catering. London, England: Routledge.

World Tourism Organisation. (2014). Measuring employment in the tourism industries: Guide with best practices. Madrid, Spain: unw To.

Zabukovec, M. (2015, 16 February). Migrantski delavci v Sloveniji: življenje na robu. Delo. Retrieved from http:// www.delo.si/ozadja/migrantski-delavci-v-sloveniji -zivljenje-na-robu.html

Zakon o delovnih razmerjih (ZDR-1). (2013). Uradni list Republike Slovenije, No. 21.

Zakon o podaljšanju prehodnega obdobja na področju prostega gibanja državljanov Republike Hrvaške in njihovih družinskih članov (Z P P O P GHR). (2015). Uradni list Republike Slovenije, No. 46.

Zakon o varnosti in zdravju pri delu (ZVZD-1). (2011). Uradni list Republike Slovenije, No. 43.

Zakon o zaposlovanju, samozaposlovanju in delu tujcev (zzsD T). (2015). Uradni list Republike Slovenije, No. 47.

Zopiatis, A., Constanti, P., \& Theocharous, A. (2014). Migrant labor in hospitality: The Cyprus experience. International Journal of Hospitality Management, 37, 111-120.

Zupan, N. (2001). Nagradite uspešne. Ljubljana, Slovenia: GV založba.

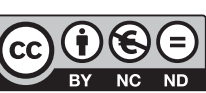

This paper is published under the terms of the Attribution- NonCommercial-NoDerivatives 4.0

International (CC B Y-NC-ND 4.0) License. 